\title{
Diseases of the small bowel in chronic diarrhea: diagnosis and treatment
}

\author{
M. Simadibrata
}

\begin{abstract}
Abstrak
Insidens diare kronik di Asia berkisar antara 0,8 - 1,0\%. Lokasi penyakit dan kelainan yang menimbulkan diare kronik dapat dibagi atas 3 kelompok yaitu usus halus, usus besar dan ekstra intestinal. Penyakit-penyakit pada usus halus terdiri dari infeksi dan noninfeksi. Penyakit-penyakit infeksi antara lain yaitu infeksi bakterial, infeksi parasit dll. Penyakit-penyakit non-infeksi yang menimbulkan diare kronik a.l. penyakit Crohn, "Celiac sprue”, enteropati OAINS, intoleransi laktose, tumor jinak, tumor karsinoid, karsinoma, komplikasi pasca bedah, obat laksatif dll. Pendekatan diagnosis terdiri dari anamnesis riwayat penyakit yang baik, pemeriksaan fisik yang teliti, laboratorium penunjang, laboratorium penunjang yang lebih spesifik termasuk foto rontgen kolon, foto rontgen "esofagogastroduodenum follow-through", "enteroclysis", pemeriksaan ileo-kolonoskopi dan endoskopi saluran cerna atas termasuk usus halus dengan biopsi untuk pemeriksaan histopatologi. Pengobatan diare kronik dibagi atas pengobatan suportif dan kausal. (Med J Indones 2002; 11: 179-89)
\end{abstract}

\begin{abstract}
The incidence of chronic diarrhea in Asia is between $0.8-1.0 \%$. The diseases and abnormalities according to the location, which can cause chronic diarrhea, are divided into three locations: the small bowel, the large bowel and extraintestinal. The small bowel diseases include infectious and non-infectious diseases. The infectious diseases are bacterial infections, parasitic infections etc. The non-infectious diseases include of Crohn's disease, Celiac sprue, NSAID enteropathy, lactose intolerance, benign tumor, carcinoid tumor, carcinoma, post surgery complications, laxative etc. The approaches to diagnosis include good anamnesis, careful physical examination, supporting laboratory tests, more specialized supporting examinations including $X$-ray of the colon, esophagogastroduodenum follow-through, enteroclysis, ileo-colonoscopy and endoscopy on the upper portion of the digestive tract including the small intestine with biopsy for histopathology examinations. The treatment for chronic diarrhea is divided into supportive and causal therapy. (Med J Indones 2002; 11: 179-89)
\end{abstract}

Keywords: small bowel, chronic diarrhea, approaches to diagnosis, treatment

Chronic diarrhea is a condition that usually causes problems both for patients and clinicians. A morbidity study in North Jakarta ${ }^{1}$ revealed that the number of patients with chronic diarrhea admitted to the hospital was around $1.0 \%$ of all patients with diarrhea, whereas the rate in Bangladesh was $0.8 \% .^{2}$ Sometimes the diagnosis of this disease is difficult and treatment is not always successful. The quality of life of the patients with chronic diarrhea is frequently impaired. The Case Fatality Rate (CFR) of chronic diarrhea in children in Jakarta is about $20 \%$. $^{3}$

The etiologies of chronic diarrhea vary from one location to another. Some experts categorize the

Division of Gastroenterology, Department of Internal Medicine, Faculty of Medicine, University of Indonesia / Dr. Cipto Mangunkusumo Hospital, Jakarta, Indonesia etiology into osmotic, secretory, abnormal motility, abnormal permeability, etc, while others group them into functional and organic or into infective and noninfective. ${ }^{1-4}$ The diseases and abnormalities according to the location can be divided into three locations: the small bowel, the large bowel, and extraintestinal. The small bowel diseases, which play an important role in chronic diarrhea, are highly variable too. They include infectious (bacterial, parasitic etc.) and non-infectious (Crohn's disease, Celiac Disease, benign tumor, carcinoid tumor, carcinoma etc). ${ }^{4-11}$ Usually, watery and non-bloody non-steatorrheic stools are caused more by small bowel diseases and bloody stools are caused mainly by large bowel diseases. ${ }^{4-7}$

Patients who suffer this chronic diarrhea usually undergo unnecessary and costly examinations and treatments. We will discuss the definition, etiology, and approach to diagnosis and treatment of chronic 
diarrhea especially in cases of small bowel abnormalities/diseases.

\section{NORMAL SMALL BOWEL}

The small bowel (small intestine) extends from the pylorus to the ileocecal valve and, depending on the tone of its muscle, measures from 3.5 to 6.5 meters in length. ${ }^{10-12}$ It is divided into three regions, namely, duodenum (the first $25 \mathrm{~cm}$ ), jejunum (the proximal $40 \%$ of the remainder of the small intestine), and ileum (the distal 60\%).

Throughout last year, a number of interesting publications further confirmed the important role of enteroscopy (small bowel endoscopy) in clinical practice, especially in chronic diarrhea cases. ${ }^{11}$ The endoscopical examination of the small bowel is characteristic. Normally, the inner lining of the duodenal bulb is usually free of folds, but the other portions demonstrate characteristic folds of Kerckring. The papilla of Vater, located along the medial wall of the descending duodenum 3 to $6 \mathrm{~cm}$ distal to the apex of the bulb, corresponds to the main papilla which drains both the bile duct and the pancreatic duct in most patients. An accessory papilla (papilla of Santorini) may be located 2 to $4 \mathrm{~cm}$ proximal to the papilla of Vater along the medial duodenal wall. ${ }^{10,12,13}$

In normal histologic appearance, the villi are not all perfectly upright, finger-like structures standing in a row perpendicular to the lumen. ${ }^{14}$ Rather, many villi tend to bend in different directions and to vary in their structure, ranging from slender, index finger-like structures to plumper, thumb-like structures with corrugated edges. Furthermore, not all villi are cylindrical with circular cross sections; many are normally leaf shaped, with elliptical cross sections.

In the first and the second portions of the duodenum, the underlying Brunner glands may be covered by broadened or shortened villi. Treitz ligament is located near the duodenojejunal junction where Brunner glands are normally rare. Villi on top of or adjacent to normal lymphoid nodules may be shortened, broadened, or absent. If one were to examine only those altered sections adjacent to a large lymphoid nodule without knowing that it was there, misinterpretation would be possible. ${ }^{15}$

The predominant cell covering the jejunal villi is the columnar absorptive cell (enterocyte). It has a refractile brush border. Occasional dark staining interepithelial lymphocytes are seen. Mitoses are confined to the crypt region and Paneth cells are located only at the crypt bases. The most common round cell of the normal lamina propria is the plasma cell, and it tends to concentrate around the bases of the crypts. Lymphocytes are fairly frequent and an occasional lymphoid nodule is normal. Isolated eosinophilic leukocytes are usually found. Occasionally pigmented, iron-containing macrophages are seen near the tips of the villi. Polymorphonuclear leukocytes are not usually seen outside blood vessels within the lamina propria of the normal small intestine. In the normal submucosa there are blood vessels, nerve ganglion cells, lymphoid cells and lymphatics. ${ }^{15}$

Normally, the terminal ileum mucosa is smooth, and blood vessels may be seen, especially with air insufflation. Kerckring folds are less marked in the terminal ileum than in the duodenum and jejunum. The appearance of the mucosa is not glistening as in the colon but more villous and dull as in the duodenum.

\section{DENIFITION OF DIARRHEA}

Diarrhea is defined as the passage of stool of more than $200 \mathrm{~g}$ per day or the passage of soft or watery stoold more than 3 times per day with or without blood and/or mucous. ${ }^{7,8,10,16,17}$

The duration of chronic diarrhea can vary substantially. Some authors suggest that diarrhea is chronic if the duration exceeds 15 days. ${ }^{4,5,8}$ Others suggest that the term chronic can only be used for diarrhea lasting at least 30 days or more. ${ }^{7,10,11,16,17}$ Another group of authors suggest the diarrhea is categorized as chronic if it lasts for at leas 3 to 6 weeks. ${ }^{18}$

Several experts use the term "persistent diarrhea" to refer to a diarrheal episode that begins acutely and continues for more than 2 weeks. This term does not include patients with chronic diarrhea due to noninfectious causes, such as gluten sensitive enteropathy, granulomatous disease or tumor producing gastrointestinal hormones.

The term infective or infectious diarrhea will be used if infection found to be the cause. The case will be diagnosed as a non-infective or non-infectious diarrhea if infection has been ruled out as being the cause. $^{8,9,19}$ 


\section{CLASSIFICATION}

According to the pathophysiology and type of stools of the patients, ${ }^{7,8,11,19}$ chronic diarrhea can be classified into:

1. Osmotic diarrhea

2. Secretory diarrhea

3. Diarrhea caused by abnormal motility of the bowel

4. Diarrhea caused by abnormal permeability of the bowel

5. Diarrhea caused by a disturbance of electrolyte transport in the enterocyte

Powell ${ }^{20}$ groups the malabsorptive, secretory and inflammatory types of diarrhea into what he calls "enterocyte damage and death with inflammatory diarrhea". He suggests a classification of chronic diarrhea into:

1. Steatorrhea (fat malabsorption)

2. Watery diarrheas that respond to fasting

3. Watery diarrheas that may or may not respond to fasting (diarrheas of mixed or uncertain pathophysiology)

4. Watery diarrheas that do not respond to fasting (true secretory diarrheas)

5. Inflammatory diarrheas

Based on the causes of the chronic diarrhea, the latter could be divided into:

1. Infective/infectious diarrheas

2. Non-infective/non-infectious diarrheas

Based on the organic abnormality found in the examination $^{19}$ chronic diarrheas can be further classified into:

1. Organic diarrheas

2. Functional diarrheas

The $\mathrm{LB}^{21}$ classifies chronic diarrheas into the following categories depending on stool characteristics:

1. Steatorrhea

2. Bloody diarrhea

3. Stools which are non bloody and nonsteatorrheic

\section{ETIOLOGY}

The abnormalities or diseases occurring in the small bowel, which are responsible for chronic diarrhea, include: :3,5-7,20,22 $^{2,2}$
A. Infective or infectious:

1. Bacterial infection and bacterial overgrowth: Pathogenic Escherichia coli, Shigella (dysenteriae, flexneri, etc.), Staphylococcus aureus, Clostridium perfringens, Yersinia enterocolitica, Mycobacterium tuberculosis, Mycobacterium avium, etc.

2. Parasitic infections, including entamoeba histolytica, Giardia lamblia, Cryptosporidium, Isospora, Blastocystis hominis, Candida albicans, Microsporidia, Trichuris trichiura, Ascaris lumbricoides, Strongyloides, Parasites in AIDS etc.

3. Tropical sprue

B. Non-infective or non-infectious:

1. Drugs or medications:

- Laxatives such as magnesium sulfate, dioctil sodium sulfosuccinate.

- Antacids containing magnesium hydroxide

- Sodium anion

- Antibiotics

- Antihypertensive drugs

- Antiarrhytmic agents

- Antineoplastic agents

- Sweeteners (sorbitol, fructose)

- Ethanol

- Caffeine

2. Hormones and neurotransmitters: Vasoactive Intestinal Polypeptide (Vipoma), Secretin, Prostaglandin E, Cholecystokinin, Cholinergic, Serotonin, Calcitonin, Gastric Inhibitory Polypeptide, Glucagon and P substance.

3. Metabolic disturbances or abnormal motility of the small bowel: Diabetes Mellitus, Scleroderma, Amyloidosis, Thyrotoxicosis or hyperthyroidism, adrenal insufficiency, post gastric resection or vagotomy, diverticular disease.

4. Disturbance of electrolyte transport in the enterocyte: Congenital Chloride Diarrhea

5. Malabsorption:

Fat malabsorption:

a. Intraluminal: Somatostatinoma

b. Mucosal:

- Drugs: colchicine, neomycin, PAS and NSAID

- Immune system diseases: systemic mastocytosis, eosinophilic gastroenteritis

- Celiac sprue

- Dermatitis herpetiformis 
- Whipple's disease

- A $\beta$-lipoproteinemia

c. Post mucosal: Intestinal lymphangiectasia

Carbohydrate malabsorption:

- Sorbitol and fructose diarrhea

- Rapid intestinal transit

- Glucose-galactose malabsorption

6. Post Surgery:

a. Bile acid diarrhea: resection or bypass of the distal ileum in Crohn's disease or postoperative adhesions

b. Short bowel syndrome

c. Gastrectomy

d. Vagotomy

e. Cholecystectomy

7. Ischemic bowel diseases

8. Radiation enteritis

9. Functional (idiopathic)

10. Inflammatory:

a. Inflammatory Bowel Disease: Crohn's disease

b. Eosinophilic gastroenteritis

c. Milk and Soy protein allergy

d. Protein-losing enteropathy

e. Miscellaneous: chronic mesenteric vascular ischemia, Behçet's syndrome or Churg-Strauss syndrome, neutropenic enterocolitis, Cronkhite-Canada syndrome

11. Tumor:

- Benign: Polyp

- Malignant: Adenocarcinoma, Carcinoid tumor, other tumor

12. Causes of steatorrhea include Crohn's disease, radiation enteritis, celiac disease, intestinal lymphoma, bacterial overgrowth states in the small intestine \& post gastrectomy syndrome

13. Causes of non-body and non-steatorrhea diarrhea include exogenous agents such as laxative abuse and recognized food/drug causes, motility disturbance (diabetic autonomic neuropathy, thyrotoxicosis and diverticular disease.

14. Others: Dihydroxy bile acid (post cholecystectomy diarrhea)

Hydroxy fatty acid

In general, the causes of osmotic diarrhea are bacterial infection, celiac disease, laxatives such as magnesium sulfacte and pancreatic insufficiency.

The etiology of Secretory diarrhea is as follows:

a. Hormones and neurotransmitters: vasoactive intestinal polypeptide, secretin, prostaglandin E, cholecystokinin, cholinergic, serotonin, calcitonin, gastric inhibitory polypeptide, glucagons and $\mathrm{P}$ substance.

b. Bacterial Enterotoxin: Vibrio cholerae, Escherichia coli, Shigella (dysenteriae and flexneri), Staphylococcus aureus, Clostridium perfringens and Yersinia enterocolitica.

c. Others: Dihydroxy bile acid (post cholecystectomized diarrhea), hydroxy fatty acid, dioctyl sodium sulfosuccinate.

The etiology of diarrhea caused by abnormal motility of the bowel: Diabetes mellitus with autonomic polyneuropathy, scleroderma, amyloidosis, thyrotoxicosis or hyperthyroidism and postgastric resection or vagotomy.

The etiology of diarrhea caused by abnormal permeability of the bowel: Celiac disease, inflammatory bowel disease, bacterial infection.

The etiology of diarrhea caused by a disturbance of electrolyte transport in the enterocyte: congenital chloride diarrhea, viral infection.

The etiology of organis chronic diarrhea: ${ }^{7}$

a. Inflammatory bowel diseases like Crohn's disease, Ulcerative Colitis

b. Bacterial Infection

c. Parasitic Infection

d. Post Surgery (Vagotomy, Gastric Resection, Cholecystectomy)

e. Drugs like Laxative abuse

f. Alcoholism

g. Tumor of the bowel (Villous adenoma)

h. Malabsorption (Tropical Sprue)

i. Metabolic diseases (hyperthyroid)

j. Hormone producing tumors (Vipoma, ZollingerEllison syndrome)

The etiology of functional diarrhea is unknown, so it can be called idiopathic diarrhea. The etiology of infective chronic diarrhea:

- Viral

- Bacterial: Salmonellosis, Shigellosis, Tuberculosis, etc.

- Fungus: Candidiasis, etc.

- Other Parasites: Entamoebiasis, Giardiasis, Blastocystis hominis infection, Trichuriasis, etc.

The etiology of non-infective chronic diarrhea:

a. Pancreas:

- Chronic Pancreatitis 
- Pancreatic Insufficiency due to other diseases

- Vipoma

b. Liver:

- Chronic Hepatitis

- Liver Cirrhosis

c. Small bowel:

- Inflammatory Bowel Disease (Crohn's disease)

- Coeliac Disease

- Carcinoid tumor and other tumor

- Carcinoma

d. Large bowel:

- Inflammatory Bowel Disease (Crohn's disease, Ulcerative Colitis)

- Microscopic, lymphocytic and collagenous colitis $^{7}$

- Carcinoid tumor and other tumors

- Carcinoma

- Metabolic/abnormal motility of the bowel:

Drugs, thyrotoxicosis or hyperthyroid, diabetes mellitus

Powell D.W. ${ }^{20}$ describes the etiologies of chronic diarrhea as follows:

1. Steatorrhea (fat malabsorption):

a. Intraluminal maldigestion: Cirrhosis and bile duct obstruction, bacterial overgrowth, pancreatic exocrine insufficiency, chronic pancreatic exocrine insufficiency, cystic fibrosis and somatostatinoma.

b. Mucosal malabsorption: drugs (colchicin, cholestyramine, neomycin, paraaminosalicylic acid/PAS and NSAID), infectious diseases (parasites like Giardia, Cryptosporidium, isospora; helminths such as strongyloides; mycobacterium avium; AIDS); immune system diseases (systemic mastocytosis, eosinophilic gastroenteritis), tropical sprue, Celiac sprue, dermatitis herpetiformis, Whipple's disease, a $\beta$-lipoproteinemia.

c. Post mucosal malabsorption: intestinal lymphangiectasia

d. Mixed causes of streatorrhea: short bowel syndrome, metabolic diseases (thyrotoxicosis adrenal insufficiency), protein calory malnutrition, liver disease.

2. Watery Diarrheas that respond to fasting:

a. Ingestion of non-absorbable solutes: magnesium-induced diarrhea and sodium anion diarrheas. b. Carbohydrate malabsorption: sorbitol and fructose diarrhea, rapid intestinal transit and glucose-galactose malabsorption.

c. Bile Acid Diarrhea:

- Severe disease, resection, or bypass of the distal ileum: In Crohn's disease or postoperative adhesions.

- Primary bile acid malabsorption: congenital or acquired.

- Bile acid malabsorption follows upper abdominal surgery, either truncal vagotomy or cholecystectomy.

\section{d. Postvagotomy diarrhea}

3. Watery diarrheas that may or may not respond to fasting (diarrheas of mixed or uncertain pathophysiology): Irritable bowel syndrome, food allergy, microscopic colitis (collagenous and microscopic colitis, pericrypt eosinophilic enterocolitis)

4. Watery diarrheas that do not respond to fasting (true secretory diarrheas): carcinoid syndrome, gastrinoma, vipoma or watery diarrhea-hypokalemia achlorhydria (WDHA) syndrome, medullary carcinoma of the thyroid, glucagonoma, villous adenomas, systemic mastocytosis, factitious diarrhea, chronic idiopathic diarrhea and pseudopancreatic cholera syndrome, diabetic diarrhea, alcoholic diarrhea, congenital secretory diarrhea.

5. Inflammatory diarrheas:

a. Inflammatory bowel disease: Crohn's of the small or large intestine or ulcerative colitis.

b. Eosinophilic gastroenteritis.

c. Milk and soy protein allergy

d. Protein-losing enteropathy

e. Chronic radiation enterocolitis

f. Miscellaneous diseases: acute mesenteric arterial or venous thrombosis, chronic mesenteric vascular ischemia, gastrointestinal tuberculosis and histoplasmosis, Behçet's syndrome or Churg-Strauss syndrome, acute graft-versus-host disease after allogeneic bone marrow transplantation, Neutropenic enterocolitis, Cronkhite-Canada syndrome.

\section{ANAMNESIS AND CLINICAL SYMPTOMS}

Steatorrhea is a type of diarrhea where the stool has a high fat content. ${ }^{22}$ It is a rather watery stool with a light color, a strong smell, a tendency to float and which is difficult to wash off. Sometimes we can see a 
layer of oil on the surface of the water. Steatorrhea indicates a maldigestion or malabsorption of fat. In most cases, the clinical symptoms are not specific and are related to the effect of malabsorption of nutrients and lack of vitamins and electrolytes. Although the three main nutrients - fat, carbohydrate and protein can all be affected by malabsorption, normally the clinical symptoms are caused by malabsorption of carbohydrate of fat. ${ }^{20}$ Malabsorption of protein or amino acid (azotorrhea) can occur, but will be difficult to detect unless the condition is already so advanced that it has caused malnutrition - the exception are cases where defects in the transport of specific amino acids has resulted in a systemic congenital illness.

Malabsorption of electrolyte and water is part of the pathophysiology of malabsorptive diarrhea. Diarrhea with blood indicates a problem in the rectum or the left part of the colon. Diarrhea with blood also indicates mucosa ulceration. Clinical symptoms depend on etiology.

The clinical symptoms of bloodless diarrhea and nonsteatorrheic also depend on the etiology. A patient with irritable bowel syndrome (IBS) usually shows a generally good condition, making his complaints disproportional to his physical condition. His diarrhea rarely occurs at night, is intermittent with constipation and accompanied by abdominal pain and rumbling. Functional dyspepsia and other non-specific complaints can result from this disease. Frequently the patient can establish a connection between diarrhea and stress or pressure. The diarrhea will disappear or abate whenever he is relaxed or on holiday. Cases of thyrotoxicosis may also cause bloodless diarrhea and non-steatorrhea. In these cases, the patient usually has fever, perspires, palpitates and suffers weight loss. Laxative abuse in sometimes difficult to diagnose, and therefore a good anamnesis is crucial for the diagnosis.

Microscopic colitis, lymphocytic and collagenous colitis are defined as an inflammation of the colorectal mucosa that is diffuse at histologic examination. These conditions do not show any abnormality during endoscopic or X-ray barium tests. The symptom consists of a chronic watery diarrhea with no specific cause. $^{23,24}$ The connection between an immunologic disease and microscopic colitis indicates a possibility of an immunologic process. Drugs such as non-steroid anti-inflammation drug (NSAID) and vascular tonic should be considered as the cause. Microscopic colitis predominantly occurs in female patients aged 50-60, but certain cases can occur in all age groups - including children. A bloodless, non-steatorrhoeic diarrhea can occur continuously or intermittently, with spontaneous or treatment-caused remission or relapses. Sometimes the patient complains of abdominal pain, nausea or vomiting. The patient is generally in a good condition and lab results are usually normal.

A 72-hour oral/enteral fast with intravenous hydration can occasionally determine the cause of the diarrhea. If it completely stops within 24 hours, it will be unnecessary to continue the fasting. Secretoric diarrhea usually eases significantly with fasting, but may continue with more than 200 gram of stool every 24 hours. A diarrhea caused by malabsorption of food will stop with fasting.

\section{PHYSICAL EXAMINATION}

Conditions observed during the physical examination are usually caused by nutrient, vitamin and electrolyte deficiencies. Patients with chronic diarrhea may suffer weight loss down to the malnutrition level, edema, muscle hypotrophy, dry skin, anemia, glossitis, dermatitis, parestesia, peripheral neuropathy, increased susceptibility to bleeding and bruising, night blindness, weakness, tetany, bone pain, loss of hair, symptoms of dehydration and shock, pain when the abdomen is pressed; in the case of colon cancer, a lump may be palpable, etc. ${ }^{22}$

Loss of weight down to the level of malnutrition is usually caused by deficiencies of fat, protein and calories. Edema and muscle hypotrophy are the results of protein deficiency. A dry and snakelike skin is caused by deficiency of essential fatty acids and zinc. Anemia is caused by deficiency of iron, folic acid and vitamin B12. glossitis and dermatitis are usually caused by deficiency in nicotinic acid. Paresthesia and peripheral neuropathy are usually the results of deficiencies of vitamins B1 and B12. A deficiency of vitamin $\mathrm{K}$ causes the patient to bleed or bruise easily. Night blindness is caused by deficiency of Vitamin A. Weakness is caused by deficiencies in Potassium, Sodium and Magnesium. Tetany and bone pain are usually caused by a deficiency in Calcium, while loss of hair is usually the result of deficiencies in zinc and protein.

Other irregularities observed during physical exam are usually determined by the original disease or the etiology of the chronic diarrhea.

In patients with pancreatitis or pancreatic cancer, there will be abdominal pain with thrombophlebitis. 
In patients with Coeliac disease, the symptoms can be a small stature, delayed menarche, mouth ulcers, eruption of itchy skin, or evidence of dermatitis herpetiformis.

In the case of Whipple's disease, there will be polyarthritis with pigmentation.

Patients with amyloidosis or rheumatoid arthritis will present with polyarthritis.

In patients with mesenteric ischemia and Crohn's disease, we will see abdominal angina, mouth ulcer, perianal fistel, sub-acute intestinal obstruction, abdominal masses, lymphadenopathy, lymphoma.

In biliary cirrhosis and sclerosing cholangitis, icterus may be noticeable.

In post-gastrectomy (Bilroth II), we will see scars on the abdomen, and blind loops formation is possible.

\section{SUPPORTING EXAMINATIONS}

Quite a few supporting examinations will be required, including three lots of stool tests that consist of routine tests, occult blood test, analysis of digestion, quantitative and qualitative tests of fat in stool, test for parasites in stool, test for microbiology in stool, routine blood test, blood chemistry, test on liver functions, test on kidney functions, test on blood glucose, test for antibody against amoebas, test for typhoid and virus infections, tests for HIV - when suspected. Other supporting examinations will also be required like ultrasonography of the abdomen, CT-scan of the abdomen, an Ileo-colonoscopic examination with biopsy for histopathology, a gastroduodeno-jejunoscopic test with biopsy for histopathology, photography of the intestine (esophagogastroduodenum followthrough or enteroclysis), endoscopic retrograde cholangiopancreatography (ERCP), magnetic resonance cholangio pancreatography (MRCP), $\mathrm{H} 2$ breath testing, etc. In selecting the supporting tests, especially for developing countries, attention should be given to the aspects of cost effectiveness and cost-benefit.

In the case of malabsorption, a special type of lab supporting test will be required to establish the clinical symptoms and certain pathophysiological mechanisms. If the patient suffers weight loss, a test of fat and serum protein will be required.$^{20}$ If the stool contains oil, it will be necessary to find out the amount of fat in the stool. If the fat in the stool exceeds 6 grams/24 hours, the condition is viewed as steatorrhea. In the case of anemia, it will be necessary to perform blood tests to find out if there are deficiencies of iron, pyridoxine, folic acid and vitamin B12. In the case of haemorrhagic diathesis, a prothrombin test is required. If the patient complains of bone pain, tests have to be conducted to determine the amounts of calcium, magnesium, phosphate and alkaline phosphatase. In the case of dermatitis and fish-like skin, it is necessary to check the contents of zinc serum in the urine.

\section{APPROACHES TO DIAGNOSIS}

There are several different approaches to diagnosing chronic diarrhea, depending on the location, population, the purpose of the diagnosis and the specific consideration of each gastroenterology expert. Despite the variety, these procedures share the same principle, namely, it should begin with an anamnesis, followed by a physical examination, supporting lab tests, more specialized supporting examinations (including X-ray of the colon, esophagogastroduodenum follow-through, enteroclysis, ileo-colonoscopy and endoscopy on the upper portion of the digestive tract including the small intestine (using duodeno-jejunoscopy) with biopsy for histopathology examinations (see Figure 1). ${ }^{7,20,25,26}$

It is fairly difficult to distinguish between problems in the intestine, the colon or other organs. It often happens that problems in both the intestine and the colon occur at the same time. Usually, a diarrhea with blood is caused by a problem in the colon, although in rare cases it can be caused by a problem in the intestine. To determine whether the problem is in the intestine, we have to start by examining the colon or the other organs including the pancreas.

What is important is all the history data that support the probability of the case being an organic or a functional diarrhea. By organic diarrhea we mean a case of diarrhea that is caused by a disorder of the intestine that has been confirmed based on histologic or biochemical tests. On the other hand, by functional diarrhea we mean idiophatic diarrhea, a diarrhea caused by food or a diarrhea caused by a problem in the intestine's motility. An anamnesis, a physical examination and a lab screening test can determine $30 \%$ of etiology of chronic diarrhea. A complete stool test, a proctosigmoidoscopy with a biopsy can determine a higher rate of the etiology of a chronic diarrhea approximately $50 \%$. With external evaluation, including collection of stool for 24 hours and fasting, an etiological diagnosis of $70-80 \%$ is attainable. 


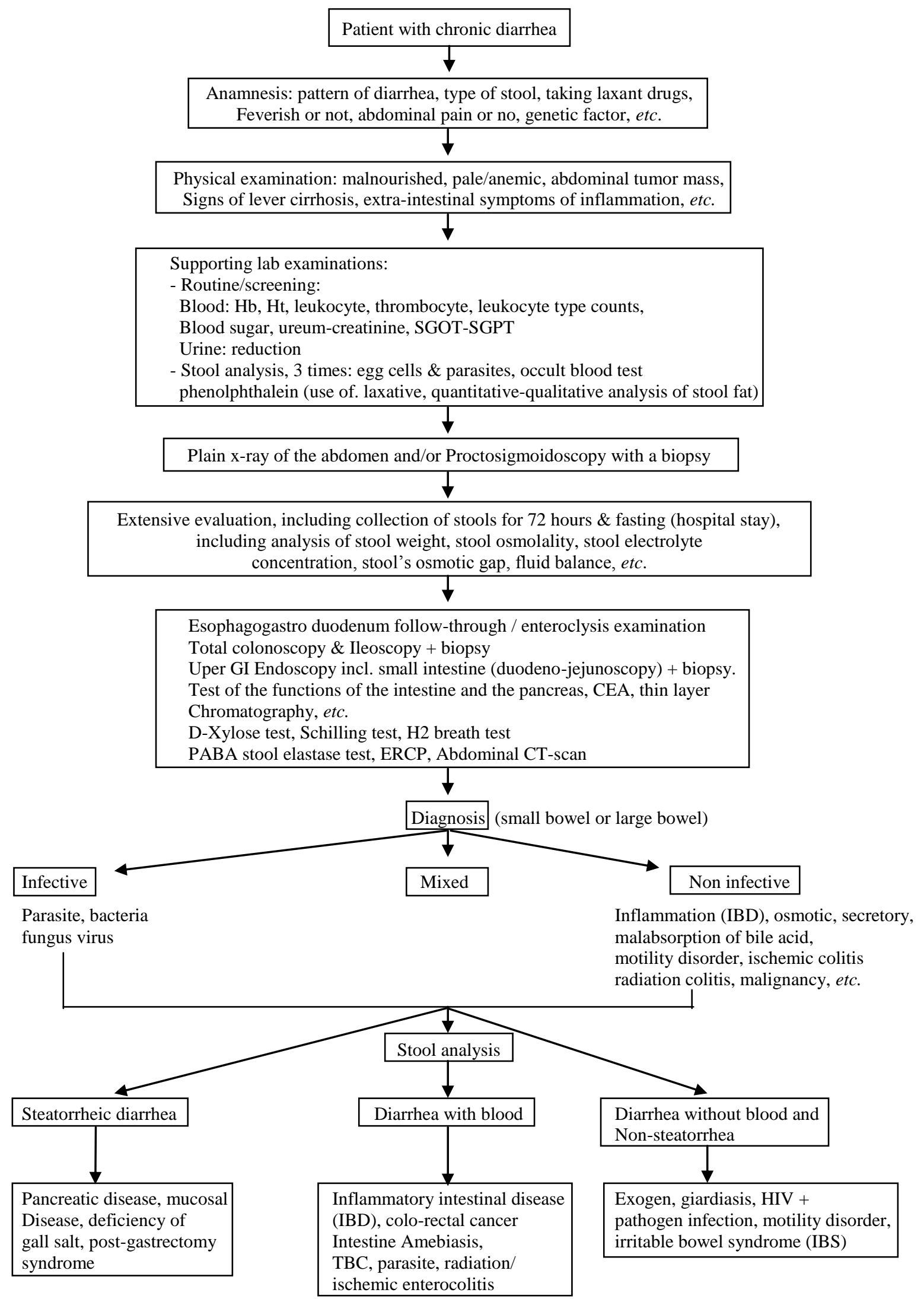

Figure 1. Diagnostic approach to the etiology of chronic diarrhea 
The criteria that point to an organic disorder are the following: 1 . The diarrhea lasts for a shorter period of time - usually less than three months; 2 . The diarrhea is more dominant at night (nocturnal); 3 . It occurs every day, not intermittently; 4 . The onset was sudden; 5 . It was followed by a weight loss exceeding five kilograms; 6. There is a history of dehydration or hypokalemia; 7 . The erythrocyte sedimentation rate is high; 8. The level of haemoglobin is low; 9. The average volume of stool per day exceeds $400 \mathrm{~g}$ (some experts use $225 \mathrm{~g}$ as the borderline). ${ }^{18,19,20,25}$ The occurance of at least three of these criteria, strongly indicates the possibility of an organic disorder, and the specificity of organic problems can reach $90 \%$ or more. On the other hand, age, presence of an abdominal pain, the number of times the patient has watery stool per day, and the description of the stool cannot serve to distinguish between an organic and a functional diarrhea. Incontinentia can occur in both of these diarrhea types.

For the test of laxative drugs use, see Table 1.Etiology of chronic diarrhea that may or may not repond to fasting is detailed in Table 2 .

Table 1. Laboratory evaluation for laxative abuse

Barium enema to test for cathartic colon (ahaustral right colon)

Sigmoidoscopy for gross presence of pseudo-melanosis coli (microscopic form is often a normal variant)

Alkalinization assay of stool: phenolphthalein, some anthraquinones, and rhubarb turn red; bisacodyl turns purple-blue

Spectrophotometry* or thin-layer chromatography of urine or stool water: Detects

anthraquinones, bisacodyl, phenolphthalein; can detect anthraquinones $>32 \mathrm{hr}$ after one dose

Measurement of stool osmolality: only useful if < $250 \mathrm{mOsm}$ per kilogram (implying dilution of stool with water or urine)

Stool osmotic gap: if $>50$ mOSM perkilogram, measure stool magnesium (normally $<45$ mmol per liter or $<30$ meq per day)

Measurement of stool sulfate and phosphate

Cited from Donowitz ${ }^{25}$

Table 2. Classification of types of chronic diarrhea on the basis of responsiveness to fasting

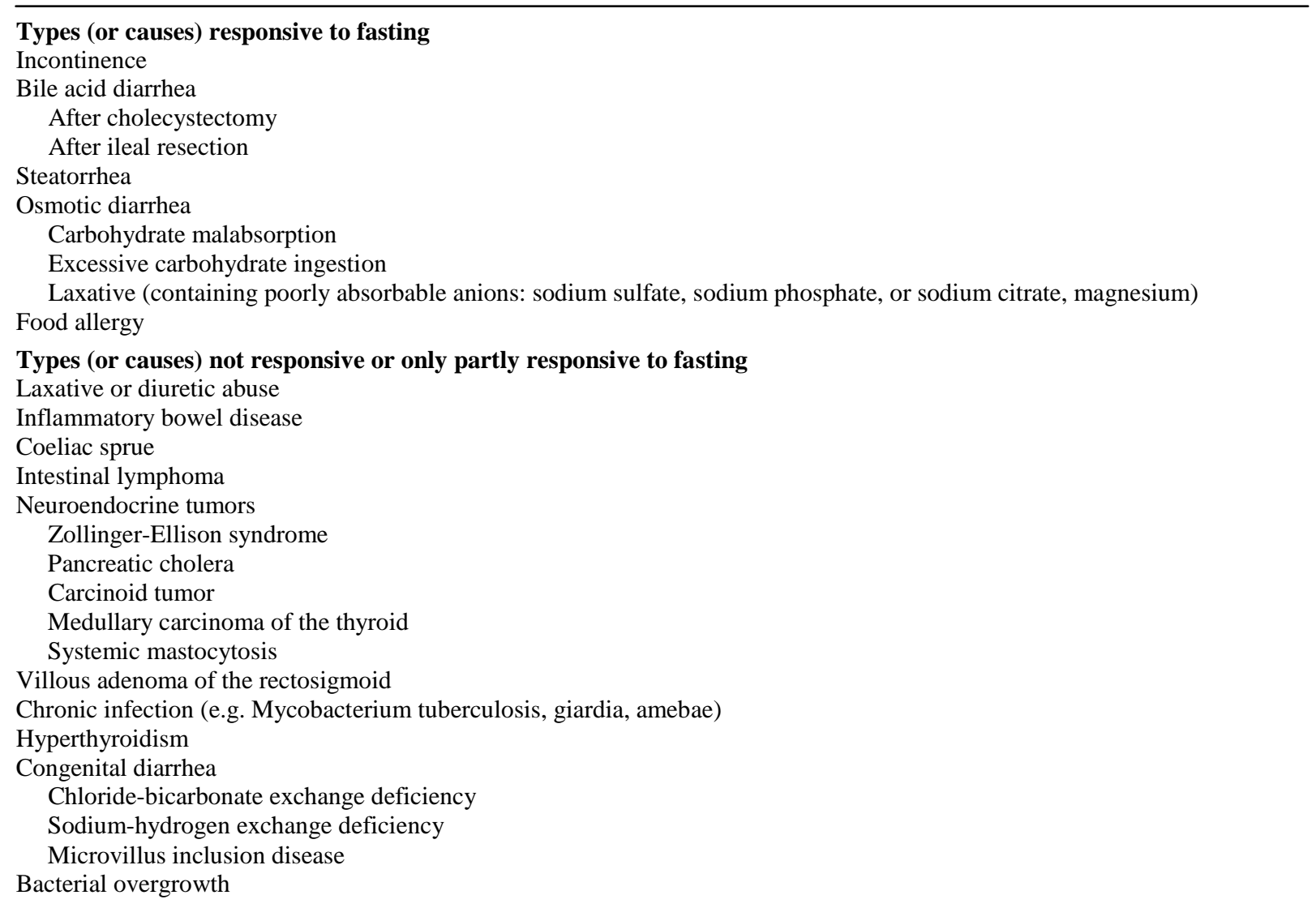

Cited from Donowitz ${ }^{25}$ 
Examination for determining the causes of steatorrhea, bloody as well as non-bloody non-steatorrhea. ${ }^{22,25}$

1. Steatorrhoea. This type of diarrhea can be caused by:

a. Pancreatic disease, which requires other tests that will support diagnosis, including GTT examination, USG or CT-scan of the abdomen as well as an ECRP test.

b. Small intestine mucous disease, which requires other tests to support diagnosis, including GTT examination, test on xylose absorption, duodenum/jejunum biopsy, H2 breath test with lactulose, barium meal follow-through/enteroclysis examination and Schilling test.

c. Liver problem, which requires additional tests including USG and CT-scan of the abdomen and ERCP.

d. Post-gastrectomy symptoms, which requires a $\mathrm{H} 2$ breath test with lactulose, a followthrough/enteroclysis barium meal test.

2. Bloody diarrhea. In addition to anamnesis and physical examination, this type of diarrhea requires barium enema of the colon-loop and sigmoidoscopy/colonoscopy with biopsy. Stool analyses to detect presence of eggs and parasites are also necessary.

3. Non-bloody, non-steatorrheic diarrhea. In addition to clinical symptoms and physical examinations, this type of diarrhea requires other tests including tests for stool parasites and colonoscopy with biopsy. In the case of irritable bowel syndrome (IBS), an exclusion of pathologic disorder of the bowel is required. Pseudomelanosis colon, a black coloration of the colon mucosa, indicative for laxative abuse, can be detected during colonoscopy. In addition to stool analysis, a duodenum biopsy is required to establish giardiasis.

If an HIV infection is suspected as being the cause of the disease, a blood screening for HIV infection is required as well as a special stool parasite test such as cryptosporidium and isospora belli. A test of the thyroid functions is required if thyrotoxicosis is suspected as the cause of the diarrhea.

\section{TREATMENT}

a. Chronic infective diarrhea:

- Supportive: Water \& electrolyte balance orally or intravenously
Nutrition orally, enterally or parenterally

Anti-fever: paracetamol, antalgin

Antispasmodic if necessary

- Causal: antibiotics or antiparasitic drugs

b. Chronic non-infective diarrhea ${ }^{20,24,25,27,28}$

- Supportive: Water \& electrolyte balance orally

or intravenously

Nutrition

Antispasmodic

- Causal: IBD: Sulfasalazin, 5-ASA, Corticosteroid

Vipoma/Carcinoid: Octreotide

\section{CONCLUSION}

Chronic diarrhea can be caused by a wide variety of small bowel diseases. A reliable diagnosis will require a systematic approach. Treatment should be based on the result of the diagnosis.

\section{REFERENCES}

1. Sutoto, Moechtar MA, Karyadi, Brotowasisto. Morbidity and mortality on diarrhoeal diseases in North Jakarta, an Urban Area. South East Jakarta. Tropical Medicine Publication health 1982: 405-11.

2. Chen LC. Control of diarrhoea diseases, morbidity and mortality: some strategic issues. Am J. Clin Nutr 1978(31):2204.

3. Suharono. Diare di Jakarta dan masalahnya. Disertasi 1985.

4. Boediarso A. Pendekatan Diagnostik-Etiologik Diare Kronik. In: Suharyono-Sunoto-Firmansyah A eds. Penanganan Mutakhir Beberapa Penyakit Gastrointestinal Anak. Pendidikan Tambahan Berkala IKA ke XVI FKUI. Jakarta, September $20^{\text {th }}$ - October $1^{\text {st }}$, 1988: 57-68.

5. Suharyono. Penatalaksanaan Mutakhir Diare Kronik. In: Suharyono-Sunoto-Firmansyah A eds. Penanganan Mutakhir Beberapa Penyakit Gastrointestinal Anak. Pendidikan Tambahan Berkala IKA ke XVI FKUI. Jakarta, September $30^{\text {th }}-$ October $1^{\text {st }}, 1988: 69-73$.

6. Gould ST. Doctor, I often get diarrhoea. In: Pounder RSantana A eds. 'Doctor, There's Something Wrong with My Guts!', A, Symptomatic Guide to Gastroenterology. London, SK \& F. 1983: 167-82.

7. Geraedts AAM. De waarde van het niet-invasieve onderzoek bij patienten met chronische diarree. Academisch Proefschrift ter verkrijging van de graad van doctor aan de Universiteit van Amsterdam, Nederland, 1987.

8. Daldiyono. Pendekatan diare kronik pada orang dewasa. In: Sulaiman HA, Daldiyono, Akbar HN, Rani AA eds. 
Gastroenterologi Hepatologi. CV Infomedika. Jakarta, 1990:34-44.

9. Jones VA and Hunter JO. Doctor, I'm allergic to food. In: Pounder R-Santana A eds. 'Doctor, There's Something Wrong with My Guts!', A Symptomatic Guide to Gastroenterology. London SK \& F. 1983:183-92.

10. Rubin E, Farber JL. Pathology. $2^{\text {nd }}$ edition. JB Lippincott. Philadelphia 1983: 649-51.

11. Rossini FP, Pennazio M. Small-Bowel Endoscopy. Endoscopy 2000; 32(2):138-45.

12. Sams V. Normal Structure and function of the small and large intestine. In: McGee JO'D, Isaacson PG, Wright NA eds. Oxford Textbook of Pathology Volume 2a. Pathology of systems. Oxford University Press. Oxford, New York. 1992: 1175-82.

13. Silverstein FE, Tytgat GNJ. Der Dunndarm. In: Praxis der gastroenterologischen Endoskpie-Atlas und Lehbuch. Stuttgart. Georg Thieme Verlag. 1999: 205-35.

14. Trier JS. Structure of the mucosa of the small intestine as it relates to intestinal function. Federation Proceedings 1967; 26(5):1391-404.

15. Haggitt RC, Rubin CE. Endoscopic Mucosal Biopsy. In: Yamada T, Alpers DH, Powell DW, Owyang CSilverstein FE eds. Textbook of Gastroenterology. $2^{\text {nd }}$ edition. JB Lippincott. Philadelphia, 1995:2836-82.

16. Turnberg LA. Diarrhoea. In: Weatherall DJ, Ledingham JGG, Warrell DA eds. Oxford Textbook of Medicine. $2^{\text {nd }}$ edition. Oxford Medical Publications/Glaxo. Volume 1. 1987: 12.18-12.20.

17. Ammon HV, Soergel KH. Diarrhea. In: Berck JE, Haubrich WS, Kalser MH, Roth JLA, Schaffner F eds. Bockus Gastroenterology Volume 1. $4^{\text {th }}$ edition. WB Saunders. Philadelphia. 1985: 125-41.

18. Kelts D. An Approach to the Pediatric Patient. In: Berck JE, Haubrich WS, Kalser MH, Roth JLA, Schaffner F eds.
Bockus Gastroenterology Volume 1. $4^{\text {th }}$ edition. WB Saunders. Philadelphia. 1985: 247-51.

19. Noerasid H, Suraatmadja S, Asril PO. Gastroenteritis (Diare) Akut. In: Suharyono, Boediarso, Halimun EM eds. Balai Penerbit FKUI. Jakarta, 1988: 51-76.

20. Powel DW. Approach tc the patient with diarrhea. In: Yamada T, Alpers DH, Owyang C, Powell DW, Dilverstein FE. Textbook of Gastroenterology Volume 1. Second edition. JB Lippincott Co. Philadelphia: 1995:813-63.

21. Teh Lip Bin. Diarrhoea. In: R. Guan, JY Kang, HS Ng eds. Management of Common Gastroenterological Problems, a Malaysia \& Singapore perspective. $2^{\text {nd }}$ edition. MediMedia Asia. Singapore, 1995:74-82.

22. Schultsz C. Escherichi coli and persistent diarrhea. Academisch Proefschrift. AMC 18 November 1999.

23. Willoughby P. Doctor, I've bloody diarrhoea. In: Punder R, Santana A eds. 'Doctor There's Something Wrong with My Guts!', A Symptomatic Guide to Gastroenterology. London. SK\&F. 1983:193-210.

24. Bogomoletz WV. Microscopic, lymphocytic and collagenous colitis. Guest lecture seminar. Department of Pathology Anatomy Faculty of medicine University of Indonesia. Jakarta, June 12-13, 1996.

25. Donowitz M, Kokke FT, Saidi R. Evaluation of patients with chronic diarrhea. N Engl J Med 1995; 332(11):725-9.

26. Morgenroth K, Kozuschek W, Hotz J. Pancreatitis. de Gruyter. Berlin, New York 1991.

27. Bruno MJ. Exocrine ter verkrijging van de graad van doctor aan de Universiteit van Amsterdam. Amsterdam 1995.

28. Suharyono, Sunoto, Firmansyah A, Boediarso A, Samsudin. Short chain peptide as the dietetic management of chronic diarrhoeas. Maj Kes Masy Indones 1991; 11:657-62. 
